\title{
Coal Mining Industry of Russia: Problems and Prospects
}

Mikhail Mikhailovich Afanasiev

Olga Anatolievna Tkacheva

Irina Borisovna Zhukova

Tatiana Georgievna Plekhanova

Sergey Petrovich Ignatenko

State Polytechnic University (NPI), The Shakhty Branch of M.I. Platov South, Shakhty, Russian Federation

\section{Doi:10.5901/mjss.2015.v6n6s3p295}

\begin{abstract}
The article deals with the problems of the coal industry of Russia and possible ways of development of the industry. The presence or absence of strategic minerals (such as coal), the presence or absence of the industrial complex, the presence or absence of highly skilled labor force, and so on., Determines the diversity of economic and social characteristics of each region. These significant differences in the levels of socio-economic development of the regions contribute to increasing social tension, leading to unpredictable migration phenomena, etc. The researchers put the problem in this regard an adequate evaluation of the socio-economic condition of the coal industry, identifying the causes of underdevelopment of some of them and the development of recommendations on equalization of the levels of development of regions. The authors acknowledge that the urgent tasks of any state is to maintain the country's territorial integrity, the prevention of social conflicts, all sorts of problems, to ensure a decent standard of living daily in Russia, there is a huge regional differentiation of socio-economic indicators matters. The current state and development of the coal industry of the Russian Federation is determined by such factors as the amount of mineral reserves, the quality and conditions of coal mining, funds, scientific and technological progress, working conditions, economic factors.
\end{abstract}

Keywords: coal mining, economics, energy sector, competitiveness, regional studies.

\section{Introduction}

The coal industry in our country has always been a subject of special pride, as the profession of miner enjoyed the same respect. And for good reason - the industry since the beginning of industrialization was of great importance for the economy. It has not lost it now. Coal reserves, Russia ranks second in the world, second only to the United States. The country's explored reserves amount to hundred ninety three billion and 3 million tons, inferred resources. (Volkov, 2010). Expert assessment characterizes the preliminary reserves of Russian coal for 600 years at the current level of resource extraction (Batyreva 2002; Izart et al., 2006).

The quality of Russian coal is very diverse: from inefficient brown coal to high-quality anthracite and coking coal securities. In Europe, a mine approaching the Russian conditions is time closed. Recently I stopped working in Ruhr's last mine in Germany, which is close to Donetsk according to its geological conditions (Kuyumchu, 2003). European countries (eg Belgium, the Netherlands and France) have stopped their mine industry at the end of the twentieth century, in the UK the process of removing mines is almost completed. Coal mined in Europe, Poland, Ukraine (Donetsk and Luhansk People's Republic) and the Russian Federation in propotional small amounts - in the Czech Republic (Schadov, 2003). The current state of the Russian coal mining and industry is characterized as a highly organized and multicomponent phenomenon. Researchers have estimated that the industry development as a very controversial and ambiguous (Voskobojnik, 2012; Batyreva, 2002; Isart et al., 2006).

Clearly, this is a huge resource, which nevertheless does not always work rationally. In the current environment, the competitive primary energy sources pressure, especially natural gas, as well as tightening the requirements for the environmental matters and standards, the coal industry can not meet now. The researchers acknowledge that today Russian coal mining, in spite of some serious problems, continues to evolve and modernize (Getmanova, 2008; Sachsenhofer et al., 2012). We believe that the prevention of ethnic and social conflicts in the coal industry (Zamaletdinov 
et al., 2014; Karabulatova, Al-Jeyran, 2014), must be present in all the industries social sphere since poor working conditions, climate, etc. (Proskura 2011; Ryazantsev et al., 2014; Ryazantsev et al., 2015; Pismennaya et al., 2015). A significant part of mines and pits were not profitable initially, as in a market economy that could not and would never be profitable (Shkurkin et al., 2015; Kobersy et al., 2015). The industry is in steep decline, as evidenced by endless protests of miners.

Experts believe that during the twenty first century. Coal will be the "transition" energy source with the subsequent transfer of the powers to other sources of energy in the next decade (Volkov, 2010; Sachsenhofer et al., 2012). The legacy of the Soviet Union, Russia has a huge, unbalanced and outdated coal complex. Some believed that the coal industry generaly is hopeless. These circumstances obliged, to carry out recovery of the industry.

\section{Materials and Methods}

Material for the study was the Russian statistics, the author's results survey mines in Rostov region, surveys locals and experts. The result data was compared with analyst experts previously obtained in both the coal mines and industry and other related fields.

The total plan funding of coal industry until 2030 - three trillion seven hundred billion rubles. However, the budget for its implementation is required to allocate the entire two hundred fifty one billion and 8 hundred million rubles, or less than nine percent of the total fundings. Considering that the industry has long been privatized, the amount is propotionaly good. The program assumes that by 2030 coal industry and production will increase to four hundred thirty million tons and will be eighty two sections and sixty four mines, and the level of productivity (coal production per person employed) five times exceeds the index of 2010 (nine thousand tons and two thousand tons, respectively). Over the entire period of the program will put five hundred five million tonnes of upgraded facilities for coal mining - on disposal of 375 million tons of capacity unpromising and unprofitable businesses and to reduce the level of depreciation of fixed assets from $70-75 \%$ to $20 \%$.

In the early 1990s, he started the first phase of restructuring (Nikolaeva, Bogoliubova \& Shirin, 2015). The coal industry has passed in "private hands" as a result of restructuring. Coal production in the country is now made 137 cuts and 91 mines with total annual production capacity of more than 370 million tonnes. Over the past 10 years, the volume of Russian coal production has increased by about a quarter, the volume of exports - almost three times. Increased (45\%) and the volume of coal enrichment. It has been completely phased out by state subsidies for the coal industry. Companies are now developing their own funds and borrowed funds. Despite a significant decline in demand for coal in the crisis years, the industry came out of them without significant problems. It once again proved its viability. In 2011, production reached the highest rate in the post-Soviet Russia - 336.1 million tonnes (of which almost 200 million have been mined in the Kuznetsk Basin). Net financial result for the whole industry in the past year exceeded 120 billion rubles.

It is envisaged that the program will reduce costs and improve the coal supplies. Thus, the reduce by 1.2 times of average distance of transportation of coal production, and 1.4 times of the domestic market. To reduce the impact of distance transport in the basin will develop the local use of coal produced, which is planned to establish a series of energy source's technology complexes, you can go to resource development of coal deposits, recovery and use of methane. In general, in accordance with the rate of formation of new centers of coal mining, coal production will be located in the east of the country. The share of Eastern Siberia will increase from 6.2\%, the Far East $-6.5 \%$.

It is supposed to create a sustainable and innovative system for the coal industry promising domestic technologies and equipment, as well as scientific and technological solutions. When creating new centers of coal production provides for mandatory construction of modern concentrators. Modern possibilities of using man-made materials of coal mines are extensive enough.

In September 2014 it produced 30,127 tonnes of coal, which is 5073 tonnes less coal compared with the period last year. This gap may be overcome by the end of the year. If you save the negative trend, the decline can be explained by the prevailing negativity as the current situation, but also possible in the association of failures in implementing the program.

\section{Results}

Based on the above we get the following conclusions:

1. Factors that provide the opportunity for growth of production:

- continued high capacity production facilities in coal mining (as of 2014 - four hundred five million tons of 
coal a year, capacity utilization amounted $87.3 \%$ );

- demands for Russian coal in foreign markets stabalized.

2. Factors limiting production growth:

- reduction of coal consumption in the domestic market, including the declining competitiveness of solid fuel in comparison with natural gas;

- declining profitability of sales as a result of faster growth in fuel prices and railway tariffs as compared to the prices of coal products;

- high concentration of production in a coal-mining region (Kuzbass).

The solution to these problems are solved theoretically, according to the program of development of coal industry until 2030. Positive aspects has been achieved already, but this is unfortunately not enough to fully revive the coal mining industry. By our opinion, it is necessary to update the BPA, improving existing recycling, and to create a complex of enterprises, depending on the operating conditions of the organization and recovered natural materials that is going to support the existing coal power company.

The greatest amount of carbon (10-30\%) is in the flotation tailings. The gravity concentration waste class one thirteen $\mathrm{mm}$ of coal may reach ten percent, and in the waste of class thirteen - 150 millimeter 4-7\%. The waste coal content of coal varies from 0 to $10 \%$. A very important factor limiting the application of coal tailings is the presence of sulfur. Its content is, for example, rocks Donbass reaches $3-4 \%$. Humidity waste depends on the method of preparation thereof. Natural moisture mudstone $4-5 \%$. Waste coal flotation extracted from sludge tanks have humidity $25-30 \%$.

Unlike overburden coal mine waste coal characterized by a high content of carbon, more stable material composition, a lower content of sandstones and mudstones great content, an increase in sulfur content and a decrease in the mechanical strength. The best additions to the ceramic materials are anthracite coal tailings.

However, the coal companies are the highest industrial polluters. This environmental damage is prolonged in nature, not only directly in the process of production, but also for many years after its termination. One of these consequences of climate change is in the direction of warming on the planet as a whole (Pismennaya et al., 2015). Solving these problems requires the resumption of Russian coal industry and to continue research on the production, transportation and use of coal-water fuel (CWF) in the energy sector and the transport sector.

\section{Discussion}

In the near future, Russia should possibly strengthen the position of the country-exporter of coal on the world coal market, as in the last ten - fifteen years there has been a sharp increase in the role of developing countries in world production (China, India, Indonesia, Venezuela and Colombia) and developed - South Africa and Australia (Lunev, 2007).

This will require detailed segmentation and country markets of importing Russian energy and coking coal;

shifting the focus of gravity exports to the Asian direction (in view of the objective of increasing energy needs of the countries of the East Asian destinations in the corner);

Carrying out the state level are extremely cautious and deeply balanced energy policies of restoration of Russia's rank as a top coal exporting countries in the European market, it is reasonable and a lot of pushing in this direction with existing and prospective competitors. As a result, there are various conflicts, particularly due to the fact that in the field of energy industry is also a significant number of migrants (Gabdrafikov et al., 2015; Karabulatova, Polivara, 2015; Ryazantsev et al., 2015; Khairullina, Karabulatova, 2014; Kobersy et al., 2015).

Otherwise, Russia will lose the European part of the world coal market (in terms of exports of steam and coking coal) in the very near future. The risks in the development of the Russian coal industry are related to the world market of large producing countries with large reserves and low production costs of coal (China, Indonesia, Malaysia and South Africa) (Troitsky, 2009).

The Russian Federation must strengthen its export policies on the world coal market, maximizing its foreign trade deliveries of coal within the next decade due to the following reasons:

- Shortage of coal in a number of countries;

- Stable trade relations prevailing in the Russian coal exports to a number of states;

- To gain the leadership in the field of steam coal import (Japan, France, Taiwan, Italy. The Netherlands, and Denmark, and more recently - Korea, Germany and the United States), as well as the import of coking coal (Japan, Korea, Italy, Taiwan, India UK, Germany, France and Spain).

The countries that should be considered promising markets: Ireland, Belgium, Norway, Sweden, Finland, Iceland, Germany (the main foreign trade partners of Russia), Austria, Switzerland, Portugal, Greece; Israel, Turkey; Laos, 
Malaysia, Thailand, the Philippines, Singapore, Taiwan. In the long run it may be considered Brazil, Argentina, Chile, Paraguay, and Uruguay.

China's case should be particular. The basis for this low production volumes and availability of the majority of fields in this country in the future, the tremendous growth demand for coal of the country due to the abrupt development of production, the geographical proximity and cheap supplies of Kazakh and Russian coal in the western and north-eastern regions of China. With China, Russia has to maintain a very cautious trade policy gradually subjugating western and northwest segments of the Chinese coal market and forcing it on the US.

Russia in the case should finely specify its policy on coal exports to individual countries. It is mandatory to maximize their supply of coal to Japan, possibly reducing the number of selling prices for coal and, most importantly, pushing Columbia, Canada, and possibly the United States, and eventually, China from the market. It is hardly possible for the rest of the competitors in the Japanese market. The same policy should be carried out in respect of Korea, forcing the United States and Canada. Russia to start deliveries of coal on the German market, where it does not take part, displacing the North America and China, and with the competent foreign trade policy in the long term and possibly Colombia. On the Spanish market - the United States. The supply of coal to India, Russia is not involved. . The UK market competitors are the US, Canada, China They would have to start for a long time, relying on long-standing and successful foreign trade relations and geographic proximity. In the market of the Netherlands, Russia should lift its market share, edging out the United States, Canada and China. The same applies to the Italian market. Russia is in the short term to try to enter the market of coal in Canada, although it is very difficult. Russia's long-standing strength the friendly foreign policy and economic relations should be to grow its share of coal supplies to the French, surpassing the United States, Canada and China in the future.

Modern economic development of the countries of the world is characterized by trends of population growth and an increase in well-being, development directions of scientific and technical progress (Kobersy et al., 2014; Beloglazov et al., 2015), the electrification of the economy. All this contributes to a dramatic increase in needs of the society in different types of energy. And because the main source of energy is non-renewable natural resources, the question naturally arises of the resource base and prospects of energy.

\section{Conclusion}

Thus, global economic crisis is having a significant consequences on the Russian coal industry. And the reduction of coal mining, the pollution of the environment, increased depression of the miners and their families. The source of contamination are waste heaps. However, reclaiming waste dumps after the closure of the enterprise, is impractical, because of all rich sources of raw materials and fuels for many processes.

Despite the difficulties and the consequences, the prospect of using raw dumps is obvious, because Recycling solves simultaneously economic, social and environmental issues, which include:

1. Extension of economic "life" of the enterprise;

2. Preservation of jobs;

3. Increasing the trade of products;

4. Competitive advantage on the background of similar products;

5. Improving and maintaining stable environmental conditions;

6. Reducing government expenditure.

Directly mined coal by-products are used for mines, waste coal and overburden. Mine overburden most frequently represented argillites, sandstones, limestones.

Due to the reduction of investment attractiveness of coal production in a number of cities and regions exacerbated social issues associated with the restructuring of the mines. The most acute problem for those settlements, where the coal industry is city-forming.

In the current market situation, to compete successfully coak products mining enterprises in the international market and preserve the level of exports of coal, as well as the viability of a number of coal mines of East Donbass, can be achieved if the improvement of equipment and technology of coal production, reduce production costs and improve ultimately, technical and economic indicators, while ensuring a high level of safety, which depends on the cost of the coal mining projects.

\section{References}

Batyreva, M.G. (2002) Socio-economic impact of restructuring of the coal industry of East Donbass // Mountain information-analytical 
bulletin (scientific and technical journal). №2. http://cyberleninka.ru/article/n/sotsialno-ekonomicheskie-posledstviyarestrukturizatsii-ugolnoy-promyshlennosti-vostochnogo-donbassa (date of treatment 08/15/2014)

Volkov, N.A. (2010) Questions of modernization of the Russian coal industry in the process of joining the World Energy // Problems of modern economy, №4. http://cyberleninka.ru/article/n/voprosy-modernizatsii-rossiyskoy-ugolnoy-promyshlennosti-v-protsesseeyo-vhozhdeniya-v-mirovoy-toplivno-energeticheskiy-kompleks (date of treatment 02.005.2015).

Voskobojnik, M.P. (2012) Long-term program of development of coal industry in Russia // Mining, №2 (96). http://www.miningmedia.ru/ru/article/anonsy/145-dolgosrochnaya-programma-razvitiya-ugolnoj-promyshlennosti-rossii (date of treatment 04/15/ 2015)

Voskobojnik, M.P. Problems of development of the coal industry in Russia // http://www.mining-media.ru/ru/article/ekonomic/1164problemy-razvitiya-ugolnoj-promyshlennosti-rossii

Gabdrafikov, I., Khusnutdinova, L., Karabulatova, I., \& Vildanov, K. (2015). Ethnoconfessional Factor in Social Adaptation of Migrant Workers in the Muslim Regions of Russia. Mediterranean Journal Of Social Sciences, 6(3S4), 213-222.

Getmanova, I.A. (2008) Economic evaluation of the use labor potential in coal-mining regions // Notes of the Mining Institute. T.

Beloglazov Denis, A., Finaev Valery, I., Zargarjan Jury, A., Soloviev Victor, V., Kosenko Evgeny, Y., \& Kobersy Iskandar, S. (2015). Efficiency of genetic algorithms in intelligent hybrid control systems. ARPN Journal of Engineering and Applied Sciences, 10(6), 2488-2495.

Karabulatova, I.S., \& Polivara, Z.V. (2015). Intraethnic installation of Ukrainian labour migrants in the preservation of linguistic and cultural identity. Mediterranean Journal of Social Sciences, 6(3), 142-148.

Khairullina, N.G., \& Karabulatova, I.S. (2014). Bailiff's social portrait. Middle - East Journal of Scientific Research, 19(3), 417-420. doi:10.5829/idosi.mejsr.2014.19.3.13686

Komarov, M.A., Aliskerov, V.A. \& Kusevich, V.L. Innovative tehnoekologiya and new challenges of technological mineralogy. Q: Interdisciplinary scientific-practical journal "Ecology of industrial production http://ivimi.ru/editions/for_readers/archive/article_ detail.php?SECTION_ID=158\&ELEMENT_ID=12138 (date of treatment 04.28.2015).

Kuyumchu, M. (2003) Coal industry restructuring and rehabilitation of mining areas in the "new" eastern states of Germany // Mountain information-analytical bulletin (scientific and technical journal). №4. http://cyberleninka.ru/article/n/restrukturizatsiya-ugolnoypromyshlennosti-i-sanatsiya-gornopromyshlennyh-rayonov-v-novyh-vostochnyh-zemlyah-germanii (date of treatment 05.15 . 2015).

Lunev, A.V. (2007) The Russian coal industry in the global energy supply. Dissertation of the candidate of economic sciences. M. pp. 27.

Nikolaeva, J. V., Bogoliubova, N. M., \& Shirin, S. S. (2015). Ecological tourism in the state image policy structure. experience and problems of modern Russia. Current Issues in Tourism, doi:10.1080/13683500.2015.1100588

Shkurkin, D., Novikov, V., Kobersy, I., Kobersy, I., \& Borisova, A. (2015). Investigation of the scope of intellectual services in the aspect of virtualization and information economy of modern russia. Mediterranean Journal of Social Sciences, 6(5S3), 217-224.

Pismennaya, E.E., Karabulatova, I.S., Ryazantsev, S.V., Luk'Yanets, A.S., \& Manshin, R.V. (2015). Impact of climate change on migration from Vietnam to Russia as a factor of transformation of geopolitical relations. Mediterranean Journal of Social Sciences, 6(3), 202-207.

Proskura, D.V. (2011) Mechanisms to solve ecological and economic problems caused by the effects of restructuring of the coal industry in the Eastern Donbass // Terra economics, № 2-3, 9. http://cyberleninka.ru/article/n/mehanizmy-resheniya-ekologo-ekonomic heskih-problem-obuslovlennyh-posledstviyami-restrukturizatsii-ugolnoy-otrasli-v-vostochnom (date of treatment 05.07. 2015).

Rogachev, M.A. \& Antonenko, E.E. (2012) Processing technogenic waste as the direction of diversification of the economy monotown // Electronic Journal "Management of economic systems". http://www.uecs.ru/uecs41-412012/item/1369-2012 -05-29-07-37-30 (date of treatment 04.18.2015).

Ryazantsev, S.V., Pismennaya, E.E., Karabulatova, I.S., \& Akramov, S.Y. (2014). Transformation of sexual and matrimonial behavior of Tajik labour migrants in Russia. Asian Social Science, 10, 174-183.

Kobersy, I.S., Karyagina, A.V., Karyagina, O.V., \& Shkurkin, D. (2015). Law as a social regulator of advertisement and advertising activity in the modern Russian information space. Mediterranean Journal of Social Sciences, 6(3S4), 9-16.

Ryazantsev, S.V., Karabulatova, I.S., Ter-Akopov, A.A., Pismennaya, E.E., \& Bozhenko, V.V. (2015). The specificity of the differential regulation of economic integration in the context of contemporary labor migration. Mediterranean Journal of Social Sciences, 6(3), 96-102.

Sidorenko, S.A. \& Sidorenko, A.A. State and prospects of the Russian coal industry. http://www.ibl.ru/konf/031209/14.html

Statistics of the coal industry in September 2014 // Ministersva Energy. The coal industry. http://www.minenergo.gov.ru/activity/coal industryl

Troitsky, P.V. (2009) The prospects of cooperation between Russia and the European Union's energy supply. Abstract of the candidate of economic sciences. M. pp. 27.

Kobersy, I.S., Ignatev, V.V., Beloglazov, D.A., \& Kramarenko, E.R. (2014). An intelligent navigator with the control of the car technical condition. ARPN Journal of Engineering and Applied Sciences, 9(7), 1094-1098.

Schadov, M.I. (2003) The restructuring of the coal industry in Poland at the present stage // Proceedings of the Irkutsk State Economic Academy. №1. http://cyberleninka.ru/article/n/restrukturizatsiya-ugolnoy-promyshlennosti-polshi-na-sovremennom-etape (date of treatment 05.10.2015).

Sachsenhofer, R.F., Privalov, V.A., \& Panova, E.A. (2012). Basin evolution and coal geology of the Donetsk Basin (Ukraine, Russia): An overview. International Journal of Coal Geology, 89(1), 26-40. 
Izart, A., Sachsenhofer, R. F., Privalov, V. A., Elie, M., Panova, E. A., Antsiferov, V. A., ... Zhykalyak, M. V. (2006). Stratigraphic distribution of macerals and biomarkers in the Donetsk basin: Implications for paleoecology, paleoclimatology and eustacy. International Journal of Coal Geology, 66(1-2), 69-107.

Islam, M. R., \& Hayashi, D. (2008). Geology and coal bed methane resource potential of the Gondwana Barapukuria coal basin, Dinajpur, Bangladesh. International Journal of Coal Geology, 75(3), 127-143.

Kobersy, I. S., Barmuta, K. A., Muradova, S. S., Dubrova, L. I., \& Shkurkin, D. (2015). The system of the methodological principles of management of enterprise development. Mediterranean Journal of Social Sciences, 6(3S4), 25-30.

Energy Statistics Yearbook. United Nations. 1997-2007. New York, 1999-2009; Energy Information Administration, USA, 1994 - 2008.

The Ministry of Energy of the Russian Federation. The coal industry. Statistics of the coal industry in September 2014. http://www.minenergo.gov.ru/activity/coalindustry/ 